\title{
Physico-chemical properties of honey from different beehives and honey sources in selected Districts of Bale Zone, Oromia Regional State, Ethiopia
}

\author{
Aynalem Teshome*, Belete Asefa and Tesfaye Amene \\ Department of Animal and Range Sciences, College of Agriculture and Natural resources, \\ Madda Walabu University, P. O. Box 247, Bale Robe, Ethiopia. \\ *Corresponding author. Email: ayenu2264@gmail.com
}

Copyright (C) 2020 Teshome et al. This article remains permanently open access under the terms of the Creative Commons Attribution License 4.0, which permits unrestricted use, distribution, and reproduction in any medium, provided the original work is properly cited.

Received 9th November, 2019; Accepted 15th January, 2020

\begin{abstract}
The aim of this study was to assess Physico-chemical properties of honey from different beehives and honey sources in selected District of Bale Zone, Oromia regional state, Ethiopia. A total 18 honey samples were collected from different hive types and honey sources for analysis of physico-chemical properties (color, moisture content, electric conductivity, $\mathrm{pH}$, acidity, ash (mineral), HMF, reducing sugars (glucose and fructose), and sucrose content). Statistical analysis was used to analyse the data collected from laboratory parts. Data related to honey quality were analyzed using General linear model of SAS software (SAS, 2008). Whenever a statically significant difference $(p<0.05)$ is observed, least significant difference (LSD) test was used to separate the means difference. Most of the laboratory results for common parameters were found in the range of the national and international standard limits. The result of physico-chemical properties showed that there was a significance difference $(\mathrm{p}<0.05)$ between hive types except for sucrose $(\mathrm{g} / 100 \mathrm{mg})$ ( $p>0.05)$. The overall mean of honey sampled from different hive types showed color (optical density) (10.86 mmpfund), moisture content $(20.34 \%)$, ash $(0.29 \%)$, electric conductivity $(0.65 \mathrm{~ms} / \mathrm{cm})$, free acidity $(57.66 \mathrm{meq} / \mathrm{gm}), \mathrm{pH}(4.2)$, hydroxy methyl furfural $(9.45 \mathrm{mg} / \mathrm{kg})$, apparent reducing sugar $(73.12 \mathrm{~g} / 100 \mathrm{mg})$, sucrose content $(0.1 \mathrm{~g} / 100 \mathrm{mg})$ while the mean values for honey sampled from different honey sources were as follows: color (optical density) (10.65 mmpfund), moisture content $(19.41 \%)$, ash $(0.23 \%)$, electric conductivity $(0.53 \mathrm{~ms} / \mathrm{cm})$, free acidity $(45.33 \mathrm{meq} / \mathrm{gm}), \mathrm{pH}(3.93)$, hydroxy methyl furfural $(16.38 \mathrm{mg} / \mathrm{kg})$, apparent reducing sugar $(67.49 \mathrm{~g} / 100 \mathrm{mg})$ and sucrose content $(0.5 \mathrm{~g} / 100 \mathrm{mg})$. Hive type and honey source had direct effects on physicochemical quality of honey. The findings show that there is a high need for techniques and technology intervention, so as to derive benefit from the large number of beekeepers in Bale zone and in the country in general both in terms of honey quality and quantity.
\end{abstract}

Keywords: Bale zone, hive type, honey quality, honey source, physico-chemical.

\section{INTRODUCTION}

The quality of honey is normally assessed by physicochemical test of its ingredients. These ingredients have substantial effects on the honey industry as they influence the storage quality, granulation, texture, flavors and the nutritional and medicinal values of the product. Internationally, certain constituents have therefore been proposed as quality criteria for honey (Bogdanov et al.,
1999), and these include, but not limited to, moisture level, electrical conductivity, reducing sugars, amount of fructose and glucose, concentration of sucrose, free acidity, total acidity, hydroxyl Methylfurfurale (HMF) and proline content. The magnitude of these physico-chemical properties of honey could be influenced, among others, by the type of storage container used (White, 1994). In this 
regard, it is assumed that the physico-chemical properties of honey can change with hive type, season of collection and honey sources.

Beekeepers in Bale zone use both traditional and modern beehives to produce honey. Support organizations promote the use of modern beehives, arguing that new technologies will yield better quality honey. However, there has been no systematic research done to determine whether beehive type and source of honey influences physico-chemical properties of honey such as moisture content, ash, $\mathrm{pH}$, total soluble solids and soluble sugars. Studies of the physico-chemical properties of honey are important for the certification process that determines honey quality (Zerrouk et al., 2011). In this study, honey from different bee hive types and honey sources were investigated for honey quality. On the other hand, there are two season of honey collection in Bale zone. In the two seasons there are variations of bee floras that affect honey quality. The other factor affecting honey quality is source of honey. This is attributed to adulteration of honey at different stages (producer, middlemen and whole seller or cooperatives) of honey sources.

Quality of honey is a key factor for both local and international markets (Krell, 1996) to enable attainment of competitive premium prices and ensure human health. Honey quality consideration is an aspect disregarded by producers and processors especially in developing countries. Quality control of honey is important to determine its suitability for processing and to meet the demand of the market. Proper understanding and standardization of honey components and attributes that are most vulnerable during processing cannot therefore be over emphasized. It is very important to study the physicochemical composition of honey, which is greatly influenced by the geographical region, floral source and climate (Jones et al., 2011). The major constituents of honey are sugars, water, proteins, enzymes, acids and minerals (FAO, 1996). The quality of honey is influenced by factors like type of beehive and sources of honey. Quality determination helped to standardize honey and identification of important intervention. These factors can hinder the potential of honey market in Bale zone, as there is little or no information on honey quality in the study area. In this study, different beehive types (modern, transitional and traditional) and sources of honey (producer, middlemen and cooperatives) were investigated for honey quality. Therefore, the objective of this study was to determine the influence of beehive type and sources of honey on physico-chemical qualities of honey in the study area.

\section{MATERIAL AND METHODS}

\section{Description of the study area}

The study was conducted in Bale Zone of Oromia Regional
State which is located at $430 \mathrm{~km}$ from Addis Ababa in Southeastern part of Ethiopia within $7^{\circ} 0^{\circ} \mathrm{N}$ and $39^{\circ} 45^{\prime} \mathrm{E}$ and $70,30^{\prime} \mathrm{N}$ and $39^{\circ} 30^{\prime} \mathrm{E}$ of latitude and longitude, respectively. The study focuses on the low lands of Bale zone (Barbare, Sawena and Harena Bulluk weredas) (BZFEDO, 2016).

\section{Laboratory analysis of honey}

The physical and chemical compositions of the honey samples were determined in the laboratory for parameters such as color, moisture content (\%), ash (mineral content) (\% by mass), reducing sugar $(\mathrm{g} / 100 \mathrm{mg})$, sucrose content (g/100mg), $\mathrm{pH}$ and acidity (meq./kg), electric conductivity, and hydroxy methyl furfural (HMF) (mg/100kg). Honey sample was taken from beekeepers, middle men and whole sellers. Laboratory analysis were done at Holeta Bee Research Center (HBRC), Ethiopia.

\section{Honey quality analysis}

To determine the quality of honey, a honey sample of $2 \mathrm{~kg}$ was randomly collected from each hive type (traditional, transitional and modern) and from each honey source (producers, middlemen and cooperatives). The collected samples from each source were analyzed according to the Quality Standard Authority of Ethiopia following the procedure of Codex Alimentarius Commission Standards (2001). Physical composition (color, moisture content, electric conductivity) and chemical compositions $(\mathrm{pH}$, acidity, ash (mineral), HMF, reducing sugar and sucrose content) of the honey samples were determined according to the Harmonized Methods of the International Honey Commission (Bogdanov et al., 1999; Bultosa, 2005).

\section{Honey color analysis}

The color of honey samples was measured according to the Pfund classifier. Briefly, homogeneous honey samples free of air bubbles were transferred into a cuvette with a $10-\mathrm{mm}$ light path until the cuvette is approximately half full. The cuvette was inserted into a color photometer Pfund honey color grader (No. 0061, made in USA) and the color grades was expressed in millimeter $(\mathrm{mm})$. Pfund grades was compared to an analytical grades of glycerol standard following the procedure of Codex Alimentarius Commission Standards (2001).

\section{Electrical conductivity}

Twenty grams $(20 \mathrm{~g})$ of honey (on dry matter basis) was dissolved in distilled water and transferred to a $100 \mathrm{ml}$ 
volumetric flask, and made up to volume with distilled water. $40 \mathrm{ml}$ of this solution was poured into a beaker and placed in a thermo stated water bath at $20^{\circ} \mathrm{C}$. Electrical conductivity measurements were obtained with a low range conductivity meter (4310 Wagtech, England) with a cell constant of 1.03 . The conductivity cell was thereafter immersed in the sample solution and the conductance in ms read after temperature equilibrium was reached. Electrical conductivity was calculated using the formula following the procedure of Codex Alimentarius Commission Standards (2001).

$\mathrm{SH}=\mathrm{K} \cdot \mathrm{G}$

Where: $\mathrm{SH}=$ electrical conductivity of the honey solution in $\mathrm{mS} . \mathrm{cm}^{-1} ; \mathrm{K}=$ cell constant in $\mathrm{cm} ; \mathrm{G}=$ conductance in ms.

The results were expressed to the nearest $0.01 \mathrm{~ms} \mathrm{~cm}^{-1}$

\section{Moisture content}

The moisture content of honey was determined using the Refractive Index of the honey in reference to the standard. The method was based on the principle that refractive index of the honey increases with solids content. A digital Abbe refractometer $\left(A T A G O^{\circledR}\right.$ Abbe refractometer, made in Japan) that could thermo stated at $20^{\circ} \mathrm{C}$ regularly calibrated with distilled water was used. For this purpose, cleaned and dried prism of the Abbe refractometer was used. The surface of the prism was covered with homogenized honey samples. The refractive index after 2 minutes was read at the corresponding moisture content from the table. Water contents of sample were measured twice and the average value was recorded and it was done following the procedure of Codex Alimentarius Commission Standards (2001). The table was derived from a formula developed by Wedmore (1955) from the data of Chataway (1932) and others:

$\mathrm{W}=\frac{1.73190-\log (R . I-1)}{0.002243}$

Where: $\mathrm{W}=$ the water content in $\mathrm{g}$ per $100 \mathrm{~g}$ honey and R.I. $=$ the refractive index

\section{Mineral (ash) content}

Ash content was determined after the sample was burnt in an electric muffle furnace (CFS 11/B, England). First the ash dish was cleaned and heated in the electrical furnace at $550^{\circ} \mathrm{C}$ subsequently cooled in a desiccators to room temperature and weighed to $0.001 \mathrm{~g}\left(\mathrm{M}_{2}\right)$. Then, 5 to 10 grams of honey sample was weighed to the nearest 0.001
$g\left(M_{0}\right)$ and put in the prepared ash dish and two drops of olive oil was added to prevent frothing. Water was removed and commences ashing without loss (by foaming and overflowing) at a low heat rising to 350 to $400^{\circ} \mathrm{C}$ by using an electrical device. A Bansun burner was used to char the sample before inserting into the furnace. After the preliminary ashing with Bansun burner, the dish was placed in the preheated muffle furnace (at $550^{\circ} \mathrm{C}$ ) and heated for 1 hour. The ash dish was cooled in the desiccators and weighted. The ashing procedure was continued until constant weight was reached $\left(\mathrm{M}_{1}\right)$. Percent ash in $\mathrm{g} / 100 \mathrm{~g}$ honey was calculated using the following formula, following the procedure of Codex Alimentarius Commission Standards (2001).

$\mathrm{ASH} \%=\frac{\mathrm{M}_{1}-\mathrm{M}_{2}}{\mathrm{M}_{0}} \times 100$

Where: $M_{0}=$ weight of honey taken, $M_{1}=$ weight of dish + ash and $\mathrm{M}_{2}=$ weight of dish

\section{$\mathrm{PH}$ and free acidity}

Ten gram $(10 \mathrm{~g})$ of honey samples was dissolved in $75 \mathrm{ml}$ of carbon dioxide-free water (distilled water) in a $250 \mathrm{ml}$ beaker and stirred with the magnetic stirrer. Then the $\mathrm{pH}$ was measured with $\mathrm{pH}$ meter (3100 Jane way, England), calibrated at $\mathrm{pH} 4.0$ and 7.0. The solution was further titrated with a $0.1 \mathrm{M}$ sodium hydroxide $(\mathrm{NaOH})$ solution to pH 8.30 (a steady reading was obtained within 2 minutes of starting the titration). For precision, the reading to the nearest $0.2 \mathrm{ml}$ using a $10 \mathrm{ml}$ burette was recorded. Free acidity, expressed as mill equivalents or mill moles of $\mathrm{acid} / \mathrm{kg}$ honey was equal to $\mathrm{ml}$ of $0.1 \mathrm{M} \mathrm{NaOH} \times 10$, and the result expressed to one place of decimal. The procedure of Codex Alimentarius Commission Standards (2001) was used. The following formula was used to determine acidity:

Acidity $=10 \mathrm{~V}$

Where: $\mathrm{V}=$ the volume of $0.1 \mathrm{~N} \mathrm{NaOH}$ in $10 \mathrm{~g}$ of honey

\section{Hydroxy methyl furfural (HMF)}

The determination of the hydroxyl methyl furfural (HMF) content was based on the determination of UV absorbance of HMF at $284 \mathrm{~nm}$. In order to avoid the interference of other components at this wavelength, the difference between the absorbance of a clear aqueous honey solution and the same solution after addition of bisulphate was determined. The HMF content was calculated after subtraction of the background absorbance at $336 \mathrm{~nm}$. Spectrophotometer operating at a wavelength range including $284 \mathrm{~nm}$ and $336 \mathrm{~nm}$ was used. A $5 \mathrm{~g}$ weight of 
honey was weighed into small beaker and transfer with total of $25 \mathrm{ml}$ of distilled water to a $50 \mathrm{ml}$ volumetric flask. A volume of $0.5 \mathrm{ml}$ of Carrez solution I was mixed with 0.5 $\mathrm{ml}$ of Carrez solution II and diluted to volume with distilled water and a drop of alcohol was added to suppress foam. It was filtered through filter paper and the first $10 \mathrm{ml}$ filtrate was discarded. Five milliliters of the filtrate was pipetted into each of two $18 \times 150 \mathrm{~mm}$ test tubes. Five milliliters of sample was pipetted out in two test tubes and $5 \mathrm{ml}$ of water was added to the one test tube and mixed well. A volume of $5 \mathrm{ml}$ of $0.2 \%$ sodium bisulphate solution was added to the second test tube and mixed well using a vortex mixer for reference solution. The absorbance of the sample solution against the reference solution at $284 \mathrm{~nm}$ and 336 $\mathrm{nm}$ in $10 \mathrm{~mm}$ quartz cells within one hour was determined. When the absorbance at $284 \mathrm{~nm}$ exceeds a value of about 0.6 , the sample solution is diluted with water and the reference solution with sodium bisulphate solution in order to obtain a sample absorbance low enough following the procedure of Codex Alimentarius Commission Standards (2001). When dilution is necessary, the amount of needed solution added using dilution formula.

The dilution, $\mathrm{D}=\frac{\text { Final Volume of Solution }}{10}$

Calculation and expression of result,

HMF in $\mathrm{mg} / \mathrm{kg}=\left(\mathrm{A}_{284}-\mathrm{A}_{336}\right) \times 149.7 \times 5 \times \mathrm{D} / \mathrm{W}$

Where: $\mathrm{A} 284=$ absorbance at $284 \mathrm{~nm}$ and $\mathrm{A}_{336}=$ absorbance at 336

$149.7=\frac{126 \times 1000 \times 1000}{16830 \times 10 \times 5}=$ constant

$126=$ molecular weight of HMF; $16830=$ molar absorptivity and $\mathrm{HMF}$ at $284 \mathrm{~nm} ; 10=$ Conversion of $\mathrm{g}$ into $\mathrm{mg} ; 1000=$ Conversion of $\mathrm{g}$ into $\mathrm{kg}$; 5 = Theoretical nominal sample weight; $\mathrm{D}=$ Dilution factor, if dilution necessary; $\mathrm{W}=$ Mass of honey sample $(\mathrm{g})$.

\section{Total reducing sugar content (before and after inversion)}

Reducing sugars were determined through reduction of Soxhlet's modification of Fehling's solution by titration at boiling point against a solution of reducing sugars in honey using methylene blue as an internal indicator. The difference in concentrations of invert sugar was multiplied by 0.95 to give the apparent sucrose content. This method was based on the original method of Lane and Eynon (1923) and was used in the Codex Alimentarius Standard (2001).

\section{Reducing sugar before inversion}

A representative quantity of about $2 \mathrm{~g}$ (W2) of the homogeneous honey sample was dissolved in distilled water and diluted to $200 \mathrm{ml}$ in a volumetric flask (honey solution). Fifty milliliters $(50 \mathrm{ml})$ of the honey solution was diluted to $100 \mathrm{ml}$ using distilled water (diluted honey solution). Fifty milliliters $(50 \mathrm{ml})$ of diluted honey solution was taken in the burette. A volume of $5 \mathrm{ml}$ of Fehling's solution A was pipetted into $250 \mathrm{ml}$ Erlenmeyer flask and $5 \mathrm{ml}$ Fehling's solution B was added. Approximately 7 to 8 $\mathrm{ml}$ of distilled water was added and heated until it starts to boil. One milliliter of $0.2 \%$ of methylene blue indicator was added and titration was completed during boiling only. Change in the color of the solution from blue to colorless was taken at the end point of the reaction. The percentage of total reducing sugar before inversion was calculated by the following formula as developed by Lane and Eynon (1923)

$\mathrm{C}=\frac{2}{W 2}+\frac{1000}{Y 2}$

Where: $\mathrm{C}=\mathrm{g}$ total reduced sugar before inversion per 100 $\mathrm{g}$ honey, $\mathrm{W} 2=$ weight $(\mathrm{g})$ of honey sample and $\mathrm{Y} 2=$ volumes $(\mathrm{ml})$ of diluted honey solution consumed.

\section{Reducing sugar after inversion}

Fifty milliliters $(50 \mathrm{ml})$ of honey solution, from the solution prepared for total reducing sugar before inversion was placed in a graduated flask, together with $25 \mathrm{ml}$ distilled water, and heated to $65^{\circ} \mathrm{C}$ over a boiling water bath. The flask was then removed from the heated bath and $10 \mathrm{ml}$ of hydrochloric acid was added. The solution was allowed to cool naturally for 15 minutes, and then brought to $20^{\circ} \mathrm{C}$ neutralized with sodium hydroxide, using litmus paper as indicator, cooled again, and the volume adjusted to $100 \mathrm{ml}$ (diluted honey solution). Then $5 \mathrm{ml}$ of Fehling $\mathrm{A}, 5 \mathrm{ml}$ of Fehling $B$ and 7 to $8 \mathrm{ml}$ of distilled water was taken in a $250 \mathrm{ml}$ conical flask and heated till it started boiling. After boiling, $1 \mathrm{ml}$ of $0.2 \%$ of methylene blue indicator was added to the flask. The titration was completed while the solution was boiling. The end point of the reaction was recorded as the blue color changed to colorless. The percentage of total reducing sugar was calculated following the procedure of Codex Alimentarius Commission Standards (2001) as follows:

$\mathrm{C}=\frac{2}{W 2}+\frac{1000}{Y 2}$

Where: $\mathrm{C}=\mathrm{g}$ total reduced sugar before inversion per 100 $\mathrm{g}$ honey, $\mathrm{W} 2$ = weight $(\mathrm{g})$ of honey sample and $\mathrm{Y} 2=$ volumes $(\mathrm{ml})$ of diluted honey solution consumed. 


\section{Apparent sucrose}

The percentage of sucrose was calculated as follows:

Apparent sucrose content $=$ (reducing sugar content after inversion - reducing sugar content before inversion) $\times 0.95$

The result was expressed as $g$ apparent sucrose per 100 $\mathrm{g}$ honey, following the procedure of Codex Alimentarius Commission Standards (2001).

\section{Data management and statistical analysis}

Data related to honey quality were analyzed using General linear model of SAS software (SAS, 2008). Whenever a statically significant difference $(p<0.05)$ is observed, least significant difference (LSD) test was used to separate the means difference. The statistical model used for analysis of the data collected for honey quality parameters assessment is presented as follows:

$Y i j k=\mu+T i+S j+e i j k$

Where: Yijk $=$ Observed honey quality parameter, $\mu=$ Overall mean, $\mathrm{Ti}=$ Effect of Hive type (traditional, transitional and modern), $\mathrm{Sj}=$ effect of source of honey (producer, middlemen and cooperative) and eijk = Random error.

\section{RESULT AND DISCUSSION}

Physicochemical properties of honey produced in the study area were analyzed and compared to Quality and Standards Authority of Ethiopia (QSAE), Codex Alimentarius Commission (CAC) and European Union $(E U)$. The physicochemical properties of the honey samples are presented in table (1 and 2).

\section{Physiochemical properties of honey from different hive types in study area}

The average pfund scale of honey sampled from different hive types in study area was 10.86 Table 1 . In the current study, honey sample color from traditional hive (13.13) was significantly $(p<0.05)$ higher than that from transitional and modern hives. There was a significance differences $(p<0.05)$ between honey sampled from transitional and modern hives. However, the overall honey color ranged from 9.23 to 13.13 on $\mathrm{mm}$ Pfund scale.

Moisture content is one of the factors that determine the shelf life of the honey during storage (Pérez-Arquillue et al., 1995). There was a significance difference $(p<0.05)$ between hive types. The highest moisture content was observed in transitional hive (22.26) followed by traditional hive (21.33) while the lowest moisture content was observed for modern hive (17.43). The present result was found to be within the recommended range of Ethiopian standards (17.5 to 21 ) and EU standard (21). The average moisture content of honey obtained from traditional hives $(16.6 \%)$ was significantly higher $(p<0.05)$ than the average moisture content of honey obtained from modern hives. This result agrees with the findings of Alemu et al. (2013) for honey in sekota district.

Electric conductivity is the indication of ionizable acids and compounds in aqueous solution and it is a good criterion for determining the botanical origin of honey, the higher their content the higher the resulting conductivity. The electrical conductivity of honey is closely related to the concentration of mineral salts, organic acids and protein. The electric conductivity of honey sampled from different hive types was presented in Table 1. The current results showed that the average electric conductivity in traditional $\left(1.30 \mathrm{mS}^{-\mathrm{cm}^{-1}}\right)$ was significantly greater $(p<0.05)$ than that of transitional $\left(0.35 \mathrm{mS} \mathrm{cm}^{-1}\right)$ and modern $\left(0.30 \mathrm{mS}^{-\mathrm{cm}^{-1}}\right)$ with the overall mean of $0.65 \mathrm{mS} . \mathrm{cm}^{-1}$. Similar result has been reported for the honey produced from different floral sources at Malaysia with mean $0.74 \mathrm{mS} / \mathrm{cm}$ and $0.41 \mathrm{mS} / \mathrm{cm}$ minimum and $0.79 \mathrm{mS} / \mathrm{cm}$ maximum values (Moniruzzaman et al., 2013) and similar result has been reported by Bekele et al. (2015) from honey produced in different districts of Bale zone.

The mean $\mathrm{pH}$ value of the honey samples analyzed is given in Table 1. There were significant differences $(p<0.05)$ between the $\mathrm{pH}$ values of honey samples obtained from traditional, transitional and modern hives (Table 1). The differences observed might be due to the variations in vegetation sources and harvesting practices. The mean $\mathrm{pH}$ value of honey of the study area lies between average value set (4.2) within the reported $\mathrm{pH}$ range for honey. This $\mathrm{pH}$ value of the honey samples were higher than those results reported by Belie (2009), Kinati (2010) and Bekele et al. (2015).

There were statistically significant differences in the acidity of honey samples collected from traditional, transitional and modern hives $(p<0.05)$ (Table 1$)$. The average free acidity of the honey obtained from hive types (57.66) in study area is greater than both the range of the Ethiopian standard value $(40 \mathrm{meq} / \mathrm{kg})$ and EU standard value $(<40)$. The current finding does not agree with that of Adgaba (1999) with Ethiopian honey mean test result of $39.9 \mathrm{meq} \mathrm{kg}^{-1}$. The finding does not agree with the findings of Gebremedhin et al. (2013), Legesse (2014) and Bekele et al. (2015). This variation might be related to bee forage type and time of storage.

The mean ash content of honey and its source mainly hive types in the study area was indicated in Table 1. Significant difference $(p<0.05)$ was observed between the ash content of honey collected from traditional, transitional and modern hives. The average $(0.29 \%)$ ash content in 
Table 1. Physiochemical properties of honey from different hive types in study area.

\begin{tabular}{lcccccc}
\hline Parameter & \multicolumn{3}{c}{ Honey sources } & Over all & \multicolumn{2}{c}{ Standards } \\
\cline { 2 - 4 } & $\begin{array}{c}\text { Traditional hive } \\
\text { (mean } \pm \boldsymbol{S E} \text { ) }\end{array}$ & $\begin{array}{c}\text { Transitional } \\
\text { hive (mean } \pm \boldsymbol{S E}\end{array}$ & $\begin{array}{c}\text { Modern hive } \\
\text { (mean } \pm \boldsymbol{S E}\end{array}$ & $\begin{array}{c}\text { According } \\
\text { mean }\end{array}$ & $\begin{array}{c}\text { According } \\
\text { to Ethiopian }\end{array}$ & to EU \\
\hline Color & $13.13 \pm 0.03 a$ & $10.23 \pm 0.08 b$ & $9.23 \pm 0.08 c$ & 10.86 & - & - \\
Moisture content & $21.33 \pm 0.08 b$ & $22.26 \pm 0.20 a$ & $17.43 \pm 0.33 c$ & 20.34 & $17.5-21$ & $\leq 21$ \\
Electric conductivity & $1.30 \pm 0.00 a$ & $0.35 \pm 0.00 b$ & $0.30 \pm 0.00 c$ & 0.65 & $\leq 0.6$ & $\leq 0.8$ \\
PH & $4.60 \pm 0.00 a$ & $3.80 \pm 0.00 c$ & $4.20 \pm 0.00 b$ & 4.20 & - & - \\
Free acidity & $97.5 \pm 0.76^{a}$ & $55.5 \pm 0.28 b$ & $20.00 \pm 0.28 c$ & 57.66 & 40 & $\leq 40$ \\
Ash & $0.66 \pm 0.01 a$ & $0.12 \pm 0.00 b$ & $0.08 \pm 0.00 c$ & 0.29 & 0.6 & $\leq 0.6$ \\
HMF & $12.35 \pm 1.47 a$ & $12.5 \pm 1.44 a$ & $3.50 \pm 0.58 b$ & 9.45 & 40 & $\leq 40$ \\
Reducing sugar & $77.17 \pm 0.60 a$ & $71.48 \pm 0.75 b$ & $70.70 \pm 0.15 b$ & 73.12 & 65 & $\geq 65$ \\
Sucrose & $0.13 \pm 0.01 a$ & $0.11 \pm 0.00 a$ & $0.06 \pm 0.03 a$ & 0.10 & 10 & $\leq 5$ \\
\hline
\end{tabular}

$\mathrm{SE}=$ standard error; Means with the same letter within the same row and class are not significantly different at $\mathrm{p}(0.05)$.

study is found within acceptable ranges of national and international standards. The results are in line with Adgaba (1999) who reported 0.1 to $1.0 \%$ ash content of honey samples of Ethiopia and Bekele et al. (2015) who reported average of $0.21 \%$ ash content of honey samples from different districts of Bale zone.

The amount of hydroxymethyl furfural (HMF) in honey is one of the important indicators of honey's quality indicating whether the honey is aged or over-heated. The very low HMF content of the honey samples analyzed in the present study implies that honey collected from the study area was fresh. Bogdanov et al. (1999) reported that HMF is generally not present in fresh honey and its content increases during conditioning and storage, depending on the $\mathrm{pH}$ and storage temperature. There is significant difference $(p<0.05)$ in HMF content between honey samples obtained from traditional and modern hives (Table 1).

The mean reducing sugars content of honey samples collected from different hive types in the study area are shown in Table 1. Honey collected from traditional hives had significantly higher $(\mathrm{p}<0.05)$ reducing sugars content than honey samples collected from modern and transitional hives (Table 1). This finding disagrees with the report of Alemu et al. (2013) in which modern hive had more reducing sugar than traditional hive in Sekota district.

The average apparent sucrose content of the study area's honey is reported in Table 1. Sucrose content of honey is used to detect adulteration of honey by addition of cane or beet sugars. There is no significant difference between hive types $(p>0.05)$ for sucrose content. The average sucrose content of the honey sampled from different hive is $0.10 \mathrm{~g} / 100 \mathrm{mg}$ which is within range of Ethiopian standard (10) and EU standards $(<5)$. The result indicates that honey sampled from hive types is natural and not adulterated. Sucrose content of honey mainly depends on botanical origin of nectar and according to
International Regulatory Standards, it should not exceed $5 \%(\mathrm{~g} / 100 \mathrm{~g})$ (Codex, 2001). The current finding is in disagreement with the report of Bekele et al. (2015) in which the mean sucrose content was $4.48 \mathrm{mg}$ in selected district of Bale zone.

\section{Physiochemical properties of honey from different honey sources in study area}

Color (mm pfund), moisture content (\%), electric conductivity $(\mathrm{ms} / \mathrm{cm}), \mathrm{pH}$, free acidity $(\mathrm{meq} / \mathrm{kg})$, ash $(\mathrm{g} / 100 \mathrm{gm}), \operatorname{HMF}(\mathrm{mg} / \mathrm{kg})$, reducing sugar $(\mathrm{g} / 100 \mathrm{mg})$ and sucrose $(\mathrm{g} / 100 \mathrm{mg})$ content of honey from different sources (produces, middlemen and cooperatives) were presented in Table 2. There is significance difference $(p<0.05)$ for color between sources of honey in which lower density is observed in farmer (9.23 pfund).

The water content of honey can naturally be as low as $13 \%$ or as high as $23 \%$ depending on the source of the honey and climatic conditions (Bradbear, 2009). The average moisture content of honey obtained from producer, middlemen and cooperatives were 18.4, 18.43 and $21.40 \%$ respectively. This value falls within the range recommended for national and international moisture content of the honey (Codex, 2001; QSAE, 2005).

The average electric conductivity of different sources was $0.53 \mathrm{~ms} / \mathrm{cm}$ which is within the range of acceptable Ethiopian standard $(<0.6)$ and EU standard $(<0.8)$ (Codex, 2001; QSAE, 2005). There is significant difference $(p<0.05)$ between the sources of honey in which honey sampled from cooperatives had higher electric conductivity than honey sampled from producer and middlemen.

The average $\mathrm{pH}$ value in study area was 3.93 , which is in acidic range. There is significance difference $(p<0.05)$ between sources of honey for $\mathrm{pH}$ values. The highest $\mathrm{pH}$ value is observed for honey sampled from middlemen 
Table 2. Physiochemical properties of honey from different honey sources in study area

\begin{tabular}{lcccccc}
\hline parameter & \multicolumn{3}{c}{ Honey sources } & Over all & \multicolumn{2}{c}{ Standards } \\
\cline { 2 - 3 } & $\begin{array}{c}\text { Farmers } \\
(\mathbf{m e a n} \pm \boldsymbol{S E})\end{array}$ & $\begin{array}{c}\text { Middlemen } \\
(\mathbf{m e a n} \pm \boldsymbol{S E})\end{array}$ & $\begin{array}{c}\text { Cooperative } \\
(\text { mean } \pm \boldsymbol{S E})\end{array}$ & $\begin{array}{c}\text { According } \\
\text { mean } \\
\text { to Ethiopian }\end{array}$ & $\begin{array}{c}\text { According } \\
\text { to EU }\end{array}$ \\
\hline Color & $9.23 \pm 0.33^{\mathrm{a}}$ & $9.63 \pm 0.06^{\mathrm{b}}$ & $13.10 \pm 0.05^{\mathrm{a}}$ & 10.65 & - & - \\
Moisture content & $18.4 \pm 0.11^{\mathrm{b}}$ & $18.43 \pm 0.12^{\mathrm{b}}$ & $21.40 \pm 0.00^{\mathrm{a}}$ & 19.41 & $17.5-21$ & $\leq 21$ \\
Electric conductivity & $0.33 \pm 0.00^{\mathrm{c}}$ & $0.56 \pm 0.00^{\mathrm{b}}$ & $0.77 \pm 0.00^{\mathrm{a}}$ & 0.53 & $\leq 0.6$ & $\leq 0.8$ \\
PH & $3.60 \pm 0.00^{\mathrm{c}}$ & $4.20 \pm 0.00^{\mathrm{a}}$ & $4.00 \pm 0.00^{\mathrm{b}}$ & 3.93 & - & - \\
Free acidity & $43.16 \pm 0.44^{\mathrm{b}}$ & $52.33 \pm 0.44^{\mathrm{a}}$ & $40.5 \pm 0.28^{\mathrm{c}}$ & 45.33 & 40 & $\leq 40$ \\
Ash & $0.11 \pm 0.00^{\mathrm{c}}$ & $0.24 \pm 0.00^{\mathrm{b}}$ & $0.35 \pm 0.0^{\mathrm{a}}$ & 0.23 & 0.6 & $\leq 0.6$ \\
HMF & $16.00 \pm 0.28^{\mathrm{a}}$ & $19.00 \pm 2.64^{\mathrm{a}}$ & $14.16 \pm 1.09^{\mathrm{a}}$ & 16.38 & 40 & $\leq 40$ \\
Reducing sugar & $64.53 \pm 0.14^{\mathrm{a}}$ & $76.15 \pm 0.58^{\mathrm{a}}$ & $61.8 \pm 10.4^{\mathrm{a}}$ & 67.49 & 65 & $\geq 65$ \\
Sucrose & $0.9 \pm 0.03^{\mathrm{a}}$ & $0.24 \pm 0.02^{\mathrm{c}}$ & $0.36 \pm 0.01^{\mathrm{b}}$ & 0.50 & 10 & $\leq 5$ \\
\hline
\end{tabular}

$\mathrm{SE}=$ standard error; Means with the same letter within the same row and class are not significantly different at $\mathrm{p}(0.05)$.

(4.20). This result agrees with the result reported by Belie (2009), Kinati (2010) and Bekele et al. (2015).

The average value of free acidity of honey sampled from different sources was $45.33 \mathrm{meq} / \mathrm{kg}$, higher than acceptable Ethiopian standard (40) and EU standard of free acidity $(<40)$ (Codex, 2001; QSAE, 2005). There is significance difference $(p<0.05)$ for free acidity between honey sampled from different sources. The high free acidity was obtained in honey sampled from middlemen (52.33). The highest free acidity may be due to duration of honey storage and cleanness of storing materials.

Over all mean of ash content of honey obtained from different sources in study area was 0.23 . The value of ash content of honey obtained in this study lies within acceptable range of Ethiopian standard (0.6) and EU standards value $(<0.6)$ (Codex, 2001; QSAE, 2005). There is significance difference $(p<0.05)$ between honey sources in which the highest ash content is observed in honey sampled from cooperatives (0.35). The current finding agrees with that of Belie (2009) and Bekele et al. (2015).

The average value of HMF $(16.38 \mathrm{mg} / \mathrm{kg})$ of honey sampled from different sources was found within acceptable ranges of Ethiopian standards (40) and EU standards ( $\leq 40)$ (Codex, 2001; QSAE, 2005). There is no significant difference $(p>0.05)$ for HMF between the sources of honey. The mean hydroxyl methyl furfural (HMF) content of the study area's honey is reported in Table 2.

The average reducing sugar $(\mathrm{g} / 100 \mathrm{mg})$ in study area for honey sampled from different sources was $67.49 \mathrm{~g} / 100 \mathrm{mg}$, which is within acceptable range by Ethiopian standards (65) and EU standards ( $\geq 65$ ) (Codex, 2001; QSAE, 2005). There is no significant difference $(p>0.05)$ for reducing sugar between the sources of honey.

The average apparent sucrose content of the study area's honey is reported in Table 2. Sucrose content of honey is used to detect adulteration of honey by addition of cane or beet sugars. There is significance difference between honey sources $(p<0.05)$ for Sucrose content. The average sucrose content of the honey sampled from different honey source is $0.5 \mathrm{~g} / 100 \mathrm{mg}$ which is within range of Ethiopian standard (10) and EU standards $(<5)$ (Codex, 2001; QSAE, 2005). The current finding does not agree with the report of Bekele et al. (2015) in which the mean sucrose content was $4.48 \mathrm{mg}$ in selected district of Bale zone.

\section{Conclusion}

The laboratory analysis results of all samples of hive types and honey sources showed that in the selected district of Bale, produced bee products are within the acceptable range of national and international quality standard in terms of all the quality parameters. The common parameters to assess honey quality were thoroughly treated based on different number of samples and sample source. These parameters are: color, moisture content, ash, electric conductivity, free acidity, $\mathrm{pH}$, hydroxyl methyl furfural, reducing sugar and apparent sucrose content. The result of laboratory analysis indicated that most of the parameter considered for this research is in the range of both Ethiopian quality standard and European commission quality standard.

\section{Recommendation}

Based on the present result, all physiochemical properties from different hive types were within the ranges of Ethiopian and EU standards. Therefore, it is necessary to expand production level and improve the honey market channels in study area. 


\section{CONFLICT OF INTEREST}

The authors declare that they have no conflict of interest.

\section{ACKNOWLEDGMENT}

The study was made possible through the financial support of Madda Walabu. The authors thank all farmers/ pastoralists of Sawena, Barbare and Harena Buluk districts of Bale zone for their willingness to give their time and for providing support during data collection.

\section{REFERENCES}

Adgaba, N. (1999, June). Quality state of grading Ethiopian honey. In Proceedings of the first national conference of the Ethiopian Beekeepers Association, Addis Ababa, Ethiopia.

Alemu, T., Seifu, E., \& Bezabih, A. (2013). Physicochemical properties of honey produced in Sekota district, northern Ethiopia. International Food Research Journal, 20(6), 30613067.

Bekele, T., Desalegn, B., \& Mitilku, E. (2015). Beekeeping practices, factors affecting production, Quality of honey and beeswax in Bale zone, Oromia region. M.sc. Thesis, Haramaya university, haramaya.

Belie, T. (2009). Honeybee production and marketing systems, constraints and opportunities in Burie District of Amhara Region, Ethiopia. Doctoral dissertation, Bahir Dar University.

Bogdanov, S., Lüllmann, C., Martin, P., von der Ohe, W., Russmann, H., Vorwohl, G., Oddo, L.P., Sabatini, A.G., Marcazzan, G. L., Piro, R., \& Flamini, C. (1999). Honey quality and international regulatory standards: review by the International Honey Commission. Bee World, 80(2), 61-69.

Bradbear, N. (2009). Bees and their role in forest livelihoods: A guide to the services provided by bees and the sustainable harvesting, processing and marketing of their products. Nonwood Forest Products, (19).

Bultosa, G. (2005). Food chemistry laboratory manual. Department of Food Science and Post-harvest Technology, Alemaya University, Ethiopia.

BZFEDO (2016). Bale zone finance and economic development office, Bale Zone Oromia region.

Chataway, H. D. (1932). The determination of moisture in honey. Canadian Journal of Research, 6(5), 532-547.

Codex Alimentarius (2001). Revised Codex Standard for Honey, Codex STAN 12-1981, Rev.1 (1987), Rev. 2.

Food and Agriculture Organization (FAO) (1996). Value added products from beekeeping (FAO Agricultural Services Bulletin No., 124). Rome, Italy.
Gebremedhin, G., Tadesse, G., \& Kebede, E. (2013). Physiochemical characteristics of honey obtained from traditional and modern hive production systems in Tigray region, northern Ethiopia. Momona Ethiopian Journal of Science, 5(1), 115-128.

Jones, S. L., Jones, H. R., \& Thrasyvoulou, A. (2011). Disseminating research about bee products. A review of articles published in the Journal of Apicultural Research over the past fifty years. Journal of Apiculture Product and Apicultural Medical Science, 3(3), 105-116.

Kinati, C (2010). Assessment of honey production system, marketing and quality in Gomma wereda south western Ethiopia. MSC thesis (unpublished).

Krell, R. (1996). Value-added products from beekeeping. FAO Agricultural Services Bulletin, 124. Food and Agricultural Organization of the United Nations. Rome, Italy, 371.

Lane, J. H. (1923). Determination of reducing sugar by means of Fehling's solution with methylene blue as internal indicator. Journal of the Society Chemical Industry, 17, 32-37.

Legesse, G. Y. (2014). Review of progress in Ethiopian honey production and marketing. Livestock Research for Rural Development, 26(1). Retrieved from http://www.Irrd.cipav.org.co//rrd26/1/lege26014.htm.

Moniruzzaman, M., Sulaiman, S. A., Khalil, M. I., \& Gan, S. H. (2013). Evaluation of physicochemical and antioxidant properties of sourwood and other Malaysian honeys: a comparison with manuka honey. Chemistry Central Journal, 7, Article number 138.

Pérez-Arquillué, C., Conchello, P., Ariño, A., Juan, T., \& Herrera, A. (1995). Physicochemical attributes and pollen spectrum of some unifloral Spanish honeys. Food Chemistry, 54(2), $167-$ 172.

Quality and Standards Authority of Ethiopia (QSAE) (2005). Honey specification: Ethiopian standard, ES 1202. Addis Ababa, Ethiopia.

Statistical Analysis System (SAS). (2008). SAS Institute Inc., Version 9.2, Cary, NC, USA.

Wedmore, E. B. (1955). The accurate determination of the water content of honeys: Part I. Introduction and results. Bee World, 36(11), 197-206.

White, J. W. (1994). The role of HMF and diastase assays in honey quality evaluation. Bee World, 75(3), 104-117.

Zerrouk, S. H., Fallico, B. G., \& Arena, E. N. (2011). Quality evaluation of some honey from the central region of Algeria. Jordan Journal of Biological Sciences, 4(4), 243-248. 